\title{
THE TAXATION OF SUBJECTS AND OBJECTS OF FORESTRY ENTERPRISES IN UKRAINE: FEATURES, MECHANISMS AND OUTLOOK
}

\author{
Petro Harasym \\ Ukrainian National Forestry University, Lviv. Ukraine \\ Nadia Klym \\ Ukrainian National Forestry University, Lviv, Ukraine \\ Oksana Hrytsak \\ Ukrainian National Forestry University, Lviv, Ukraine
}

\begin{abstract}
The subject of the study in this article is the peculiarities of the taxation of forestry enterprises in Ukraine. The current problem is determined by changes in tax legislation, which will negatively affect the activity of forestry enterprises, raise the prices of lumber, lower the quality of forestry indicators, lead to a decline of hunting sector, as well as an insufficiency of financial support for forestry development in general. The purpose of the research is to identify the current state of forestry in Ukraine, to identify features and urgent issues in taxation of forestry enterprises, and to outline areas for optimizing the tax policy of the state in relation to forestry enterprises. The findings of the study are the results of the analysis of the current tax legislation of Ukraine, which allowed issues of forestry taxation to be identified, in particular, with regard to a new approach to calculation and payment of a new land tax on forests (land tax). It establishes that the application of rates under the new tax will lead to a rise in prices of wood and will slow or stop forest reproduction in Ukraine. Such tax regulation of forestry can lead to a number of negative consequences for the economy as a whole. The study concludes with the suggestions to cancel this new tax collection on forestry land and to make appropriate amendments to the Tax Code of Ukraine.
\end{abstract}

Keywords: subject of forestry enterprises, object of forestry enterprises, forestry, taxation, tax optimization, tax policy

DOI: http://dx.doi.org/10.15549/jeecar.v6i2.403

\section{INTRODUCTION}

Forests are multifunctional in their ecological nature and of great importance to society.
Among the main functions of forestry enterprises are the provision of forest resources, recreation, protection, water protection, and sanitary-hygienic functions. According to the 
State Forest Resources Agency of Ukraine (www.dklg.kmu.gov.ua), the total area of forest land belonging to the forest fund of the state, as of 2018 is 10,4 million hectares, and the country's forests occupy $15,9 \%$ of the territory. Despite its small forest cover, however, Ukraine occupies the 9th rank in Europe in terms of forest area, and 6th in terms of forest resources.

The main macroeconomic indicators of Ukraine for 2017 (www.ukrstat.gov.ua) also confirm the significance of the field of economic activity we are investigating: the forestry sector, combined with agriculture and fisheries, occupies 3rd place in the structure of Ukraine's GDP, with 13,8 \% in 2016, and 12,1 \% in 2017 (www.ukrstat.gov.ua). The public administration and defense, education, healthcare, and social assistance sectors have almost the same share in the GDP (1st place is industry, while 2nd is wholesale and retail trade, repair of motor vehicles and motorcycles, transportation, warehousing, postal and courier activities, arrangement of lodging and catering).

In a study comparing the taxation of subjects and objects of forestry entities in foreign countries such as Canada, USA, Germany, and Poland with domestic experience (Moroz), the author states that the main objects of paying taxes in forestry are wood, logging volume, rights on forest land, as well as the land itself. The unity of views on the formulation of forest policy of the taxation entities of all countries determines the key principles of sustainable development. However, each of these countries adapts their action programs to their own legislation and standards, each of which differently define key aspects, such as: ownership of forests; principles of taxation of forestry entities (forest owners); and sources of financing for business entities.

Therefore, for the sustainable development of forestry in Ukraine, as one of the strategic sectors of the state's economic activity, creating sufficient financial support for forest conservation and forest reproduction is important, as is the problem of optimizing the taxation of forestry enterprises. The tax component has always been decisive in the formation of an enterprise management system, in particular cost-oriented management (Yaremko, Plekan, Kantslir, Andrejkiv 2018). It is also a source for the redistribution of budgetary resources for forestry development.

In accordance with this research issue, the article substantiates the hypothesis that although the increase in the tax burden on forestry enterprises increases the amount of tax payments toward budgets at the respective levels, it is also accompanied by an increase in the intensity of felling, as well as by a decrease in the level of reproduction of forest resources. At the same time, legislative initiatives on the introduction of a land tax, together with rent for the special use of forest resources, will double the taxation of natural resources (land under construction) and increase the risk of stopping of most forestry enterprises.

\section{LITERATURE REVIEW}

Analysis of recent publications on the issue and highlighting unresolved areas of the overall issue.

Studies on taxation of forestry enterprises were conducted by Yu. Marchuk (2018), Yu. Tunytsya (2018), S.M. Tkachiv (2017), O.I. Furdychko, A.M. Bobko (2013), S.I. Lebedevych (2014), V.P. Moroz (2010), I.M. Syniakevych, I.P. Soloviy, O.V. Vrublevskaya (2008), M.T. Kudryk (2009), and Z.O. Tolchanova (2008). The research of the aforementioned authors is local in nature, particularly in terms of the separate direction of activity of the forestry enterprise, the separate tax (features of tax calculations for it), and the study of forest farms at the level of agriculture, etc. Forestry is an independent form of economic activity for the country; therefore, comprehensively studying the features of activity and taxation of forestry enterprises would be reasonable.

\section{Formulation of research aims (objective).}

The purpose of the research is to identify the current state of forestry in Ukraine and to determine the specific and urgent issues in the taxation of forestry enterprises, as well as the impact of resource payments on the tax burden for the forest industry and the reproduction of forest resources.

The general scientific and special methods that were used to achieve this goal and to 
resolve corresponding tasks were scientific generalization, economic and structural analysis, and the comparison method, all of which were used to assess the state of formation of universal competences in EU member states. Statistical, graphical and tabular methods were used to summarize the results of the empirical study of forestry subjects and objects in Ukraine.

\section{Outlining of key findings and their justification.}

According to the State Forest Resources Agency of Ukraine (www.dklg.kmu.gov.ua), the total area of forest lands belonging to the forest fund of Ukraine is 10,4 million hectares, including 9,6 million hectares covered with forest vegetation. Forests grow in three natural zones (Polissya, Forest-steppe, Steppe) in the Carpathians and mountainous regions of Crimea, which have sharp differences with regard to forest vegetation conditions.

In Figure 1 we will consider the main indicators of forestry enterprises in Ukraine (Fig. 1).

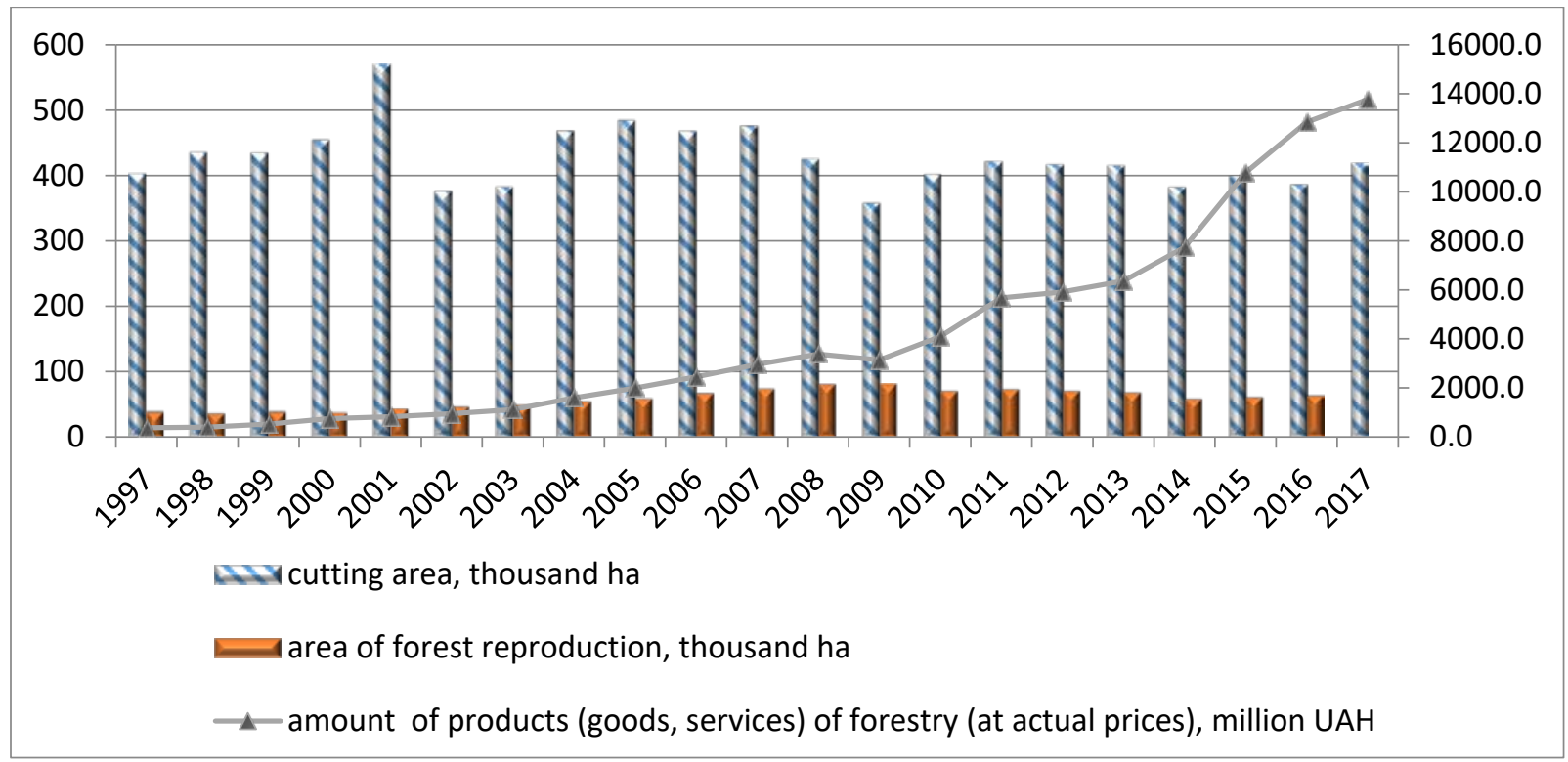

Figure 1. Main indicators of forestry activity in Ukraine, 1997-2017. Source: Created according to the State Statistics Service of Ukraine (Main indicators of forest management (1990-2017), www.ukrstat.gov.ua)

As can be seen in Fig. 1, in Ukraine (19972017), the volumes of products (goods and services) of forestry increased in very considerable volumes, and areas of felling and areas of forest reproduction experienced slight fluctuations. However, in order to carry out a comparative analysis of the data in Fig. 1, taking into account the inflation index, which directly influences the actual prices of products (goods and services) of forestry enterprises (Table 1 ), is necessary.

From Table 1 we can conclude that in 2017, compared to 1997, there was an increase of revenue from forest products by UAH 13401.6 million, which is a $3592.9 \%$ growth (by indexes for 1997-2017 - by 13272,2 million UAH and $2,641.8 \%$ respectively), indicating the effective functioning of forestry enterprises in Ukraine. In turn, the area of felling of forests for the 20 years under investigation remained practically unchanged, with the amount of logging in 2017 , as compared to 1997 , increasing by $102,4 \%$. The average age of forests in Ukraine is more than 60 years old, which implies a gradual aging of forests that can also lead to deterioration in their health. Protection of forests from pests and 
forest diseases is carried out by biological and chemical methods.

Table 1. Comparison of Aggregated Forestry Indicators in Ukraine for 1997 - 2017

\begin{tabular}{|c|c|c|c|c|c|}
\hline \multirow{2}{*}{$\stackrel{\circ}{\stackrel{\varrho}{\Xi}}$} & \multirow[b]{2}{*}{ Indicators } & \multicolumn{2}{|l|}{ Years } & \multirow[b]{2}{*}{ 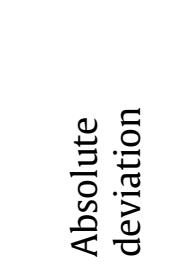 } & \multirow[b]{2}{*}{ 总 } \\
\hline & & 1997 & 2017 & & \\
\hline 1 & $\begin{array}{l}\text { Amount of forestry products (goods } \\
\text { and services) (at actual prices), million } \\
\text { UAH }\end{array}$ & $\begin{array}{l}373,0^{1} \\
502,4^{3}\end{array}$ & 13774,6 & $\begin{array}{l}13401,6^{2} \\
13272,2^{3}\end{array}$ & $\begin{array}{l}3592,9^{2} \\
2641,8^{3}\end{array}$ \\
\hline 2 & Clear-cutting of a forest, ha & 443683,0 & 419113,0 & $-24570,0$ & $-5,5$ \\
\hline 3 & Logging, thous. $\mathrm{m}^{3}$ & 10833,0 & 21923,0 & 11090,0 & 102,4 \\
\hline 4 & Number of wildland fires, units & 2771,0 & 3131,0 & 360,0 & 13,0 \\
\hline 5 & $\begin{array}{l}\text { Area of forest lands damaged by fires, } \\
\text { ha }\end{array}$ & 1717,0 & 5939,0 & 4222,0 & 245,9 \\
\hline 6 & $\begin{array}{l}\text { Burned and damaged wood on the } \\
\text { stump, } \mathrm{m}^{3}\end{array}$ & 38051,0 & 149775,0 & 111724,0 & 293,6 \\
\hline 7 & Forests reproduction area, thous. ha & 33,7 & 64,7 & 31,0 & 92,0 \\
\hline \multicolumn{6}{|c|}{$\begin{array}{l}{ }^{1} \text { Indicator of amount of forestry products (goods and services) (at actual prices) started } \\
\text { being tracked by the State Statistics Co mmittee of Ukraine in } 1997 \text { and was for this } \\
\text { period } 373,0 \text { million UAH }\end{array}$} \\
\hline \multicolumn{6}{|c|}{${ }^{2}$ to define the absolute and relative deviation, data for the period of 1997 was taken } \\
\hline \multicolumn{6}{|c|}{$\begin{array}{l}{ }^{3} \text { indexed to actual prices in } 2017 \text { according to data (Consumer price indices for 1992-2017, } \\
\text { WWW.ukrstat.gov.ua) }\end{array}$} \\
\hline
\end{tabular}

Source: Calculated by the authors on the basis of the data from the State Statistics Committee of Ukraine (Main indicators of forest management (1990-2017), www.ukrstat.gov.ua)

The indicators on woodland fires have had a negative tendency. In 2017, wildfires covered more than $245,9 \%$ of forest lands than they did in 1991. This situation led to loss and damage to forests of $111724.0 \mathrm{~m}^{3}$, which is almost 4 times more loss than at the beginning of the existence independent Ukraine. This is mainly due to issues in the management of forestry, the lack of budget funding for preventive measures, qualitative investigations, and the state of the main sources of funding for forestry.

Consequently, more than half of Ukraine's forests are man-made and require intensive care. As a result, we note that the forests of
Ukraine have not been depleted, and there is positive growth in the forest reproduction index as compared to the first years of independence of the country (by 92\%). The only unresolved issue that remains on the part of public authorities is of directing state and local budgets to the development of forestry in Ukraine.

Starting from 2010 and through the present, there has been a steady growth of contributions to the budget of taxes and compulsory payments by enterprises of the State Forest Resources Agency of Ukraine (www.komekolog.rada.gov.ua), from 1,5 million $\mathrm{UAH}$ in 2010 to 5 million UAH in 2018; 
however, the situation of budget financing for forestry enterprises is directly reversed. As such, since 2013, funding has fallen from 0,6 million UAH to 0,1 million UAH in 2018 (Fig. 2).

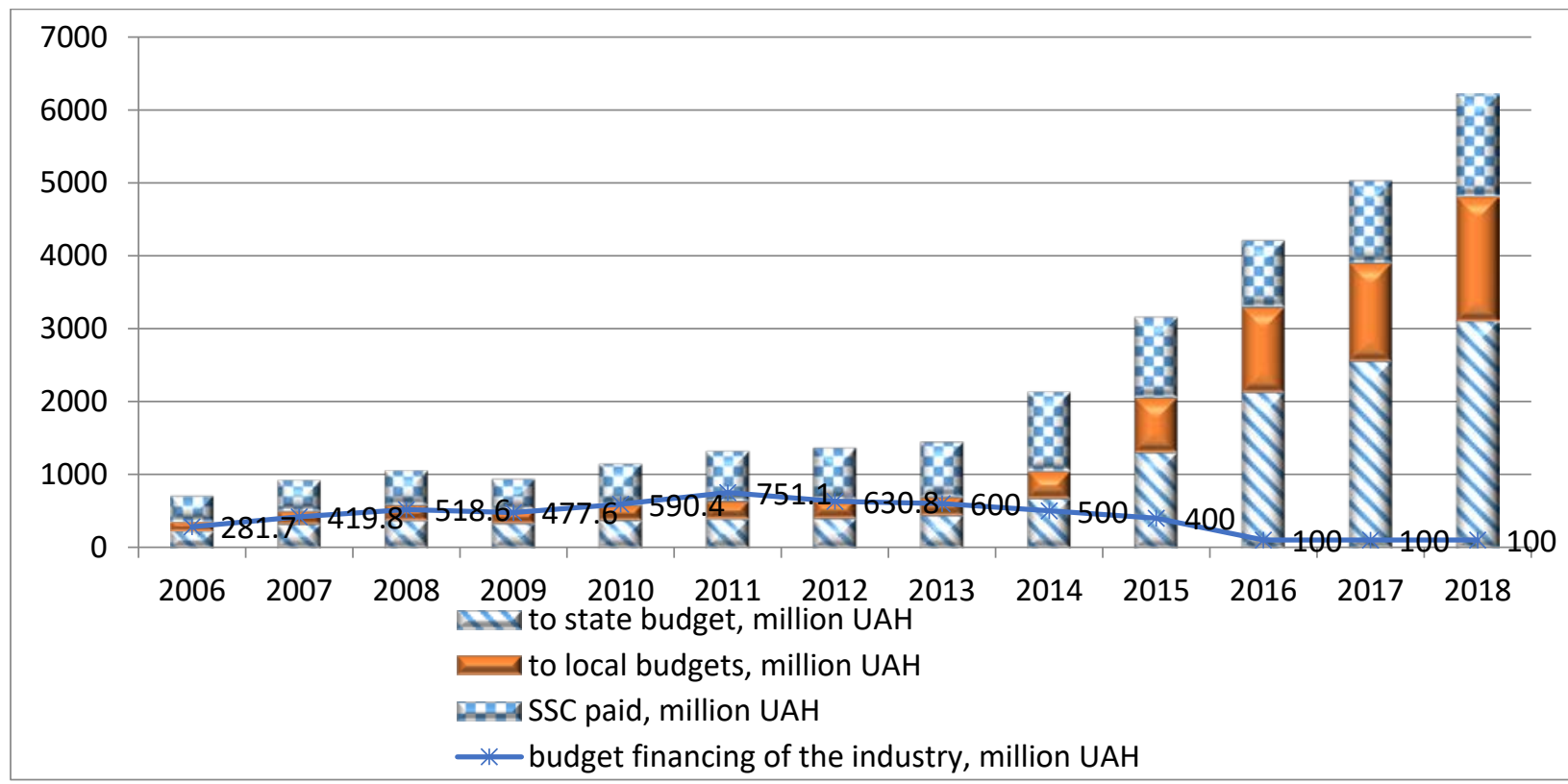

Figure 2. Dynamics of the introduction of taxes and mandatory payments by enterprises of the State Agency of Forest Resources of Ukraine into the budget, UAH millions

In 2018, the Single Social Contribution (SSC) was paid in the amount of 6,211.6 million UAH (20\%, or $1,005.1$ million UAH more than the corresponding period in 2017). As a whole, 4,809.7 million UAH of taxes, duties, and compulsory payments (except for SSC) were paid to the budget, which is 905,5 million UAH (23\%) more than in 2017, of which 3.100 .9 million UAH (65\%) is allocated to the state budget, and 1,708.8 million UAH to the local budget (35\%).

Considering the peculiarities of accruing the above taxes, levies, and mandatory charges paid by forestry enterprises, it should be noted, first of all, that forestry enterprises use the general tax system or are small private enterprises which use the simplified taxation system. In the structure of taxes, fees, and charges paid by forestry entities in 2018, the VAT amounted to $39.6 \%$, the personal income tax amounted $24.4 \%$, the rent for special use of forest resources amounted $21.2 \%$, and other taxes, fees and mandatory charges amounted $14.8 \%$, according to our calculations (www.dklg.kmu.gov.ua). At the same time, the impact of the quantity of tax on the object of taxation is decisive. For example, VAT accounts for $20 \%$ of revenues from sales of products, works, and services. Income tax makes up $18 \%$ of the financial result of the forestry enterprise (before tax), while the immovable property tax is $1-2.7 \%$ of the minimum wage per residential property area. An environmental tax, paid in accordance with the class of hazardous pollutants per 1 ton, plus land fees are $0.3-3 \%$ of the normative monetary valuation of a unit of land area. The rent for special use of forest resources consists of 10$15 \%$ for timber harvested in the order of cutting for main use and/ or timber harvested during the implementation of certain measures. Finally, the fee for use of water resources is UAH 72,25 per $100 \mathrm{~m}^{3}$.

Thus, tax payments should stimulate the management of ecological and balanced forest usage, not just ensure the fiscal function of the tax system. After all, considering the level of tax burden on a specific forestry enterprise (as an example, we used the reporting data of SE "Vygodske forestry"), the forecast model (Table 2 ) indicates its further growth. 
Table 2. Model of tax and payment forecasting at SE "Vygodske forestry"

\begin{tabular}{|l|l|l|l|l|l|}
\hline Basic data & \multicolumn{4}{l|}{ Design parameters } \\
\hline Years $(n)$ & $\begin{array}{l}\text { Taxes and } \\
\text { payments thousand } \\
\text { UAH }(y)\end{array}$ & Time $t$ & \multicolumn{1}{|l|}{$t^{2}$} & $y \cdot t$ & $\begin{array}{l}\text { Theoretical amount of } \\
\text { taxes and payments } y_{t}= \\
a+b \cdot t\end{array}$ \\
\hline 2014 & 19357 & -2 & 4 & -38714 & 14813,6 \\
\hline 2015 & 19946 & -1 & 1 & -19946 & 22109,8 \\
\hline 2016 & 21879 & 0 & 0 & 0 & 29406,0 \\
\hline 2017 & 40074 & 1 & 1 & 40074 & 36702,2 \\
\hline 2018 & 45774 & 2 & 4 & 91548 & 43998,4 \\
\hline Paзом & 147030 & - & 10 & 72962 & 147030 \\
\hline Forecasting of parameters & - & 3 & - & - & 51294,6 \\
\hline 2019 & - & 4 & - & - & 58590,8 \\
\hline 2020 & & \multicolumn{5}{|l|}{} \\
\hline
\end{tabular}

$\mathrm{a}=\frac{\sum y}{n}=\frac{147030}{5}=29406$ thousand $\mathrm{UAH}-$ the average for the 5 years.

$\mathrm{b}=\frac{\sum y \cdot t}{\sum t^{2}}=\frac{72962}{10}=7296,2$ thousand UAH - the average for the 5 years.

The equation of the line $y_{t}=a+b \cdot t$ takes the form : $y_{t}=29406+7296,2 \cdot t$

Forecasting taxes and payments for future periods:

$$
\begin{aligned}
& \text { - y } 2019 \text { p. } \mathrm{t}=3 \text {, hence } y_{t}=29406+7296,2 \cdot 3=51294,6 \\
& \text { - y } 2020 \text { p. } \mathrm{t}=3 \text {, hence } y_{t}=29406+7296,2 \cdot 4=58590,8
\end{aligned}
$$

Among the taxes for the use of natural resources for forestry enterprises, rent for their special use of land is a particular one. The direct payers of this rent are forest users who make special use of forest resources on the basis of special permits (forest harvester or forest ticket), or under the terms of a long-term temporary use of forest resources contract. For rent payment on the special use of forest resources (features of harvesting in 2018, www.news.dtkt.ua), the object of taxation is wood on the stump.

The level of payment of rent payments is directly dependent on the level of the forested area. The tax burden on an enterprise depends on species composition, age, structure, log size, cost of timber, and selling price at the market. The rent for the special use of natural resources is a component of the cost of harvesting per cubic meter of wood, and accounts for $0.1 \%$ of tax revenues in the structure of all revenues of the consolidated budget of Ukraine (www.ukrstat.gov.ua). The analysis of the dynamics of payment by the state enterprises of the State Agency of Forest Resources of Ukraine on the rent for special use of forest resources in 2015-2018 by type of budget is presented in Table 3.

As can be seen in Table 3, the amount of rent for the special use of forest resources by forestry enterprises has tended to grow annually, in contrast to the amount of this tax paid to local budgets in 2017 (362,0 million UAH).

The amount of tax paid by forestry enterprises does not characterize the actual tax burden and is often tied to production volumes. Special payments (currently rentals) should encourage the rational use and reproduction of forest resources and be relevant to ecosystem performance. Therefore, in our opinion, the level 
of tax burden from special tax should be area and the amount of unauthorized felling. determined by calculations per hectare of forest

Table 3. Rent for special use of forest resources, paid by state enterprises of forestry for 2015-2018 period, UAH million*

\begin{tabular}{|c|c|c|c|c|c|c|c|c|c|c|}
\hline \multirow{2}{*}{$\begin{array}{l}\text { Budget } \\
\text { Type }\end{array}$} & \multicolumn{4}{|l|}{ Years } & \multicolumn{3}{|c|}{ Absolute Deviation } & \multicolumn{3}{|c|}{$\begin{array}{l}\text { Relative } \\
\text { Deviation, \% }\end{array}$} \\
\hline & 2015 & 2016 & 2017 & 2018 & $\begin{array}{l}2018- \\
2015\end{array}$ & $\begin{array}{l}2018- \\
2016\end{array}$ & $\begin{array}{l}2018- \\
2017\end{array}$ & $\begin{array}{l}2018- \\
2015\end{array}$ & $\begin{array}{l}2018- \\
2016\end{array}$ & $\begin{array}{l}2018- \\
2017\end{array}$ \\
\hline $\begin{array}{l}\text { State } \\
\text { Budget }\end{array}$ & 431,4 & 461,9 & 464,0 & 541,6 & $+110,2$ & $+79,7$ & $+77,6$ & $+25,5$ & $+17,2$ & $+16,72$ \\
\hline $\begin{array}{l}\text { Local } \\
\text { Budget }\end{array}$ & 309,2 & 456,0 & 362,0 & 480,6 & $+171,4$ & $+24,6$ & $+118,6$ & $+55,4$ & $+5,39$ & $+32,8$ \\
\hline
\end{tabular}

Source: Calculated by the authors according to the data of the State Forest Resources Agency of Ukraine (www.komekolog.rada.gov.ua)

At present, the issue of taxation of forestry enterprises has been complicated by the fact that on July 10, 2018, the Law of Ukraine, dated July 10, 2018, No. 2497-VIII "On Amendments to the Tax Code of Ukraine and Certain Laws of Ukraine on Stimulation of the Formation and Activity of Family Farms" was signed on August 16, 2018. Changes made to paragraph 273.1 of the Tax Code of Ukraine declared the need to pay, in addition to rent, another new tax on all forest lands; that is, actually implementing double taxation of the same land. Therefore, we consider these tax innovations in more detail.

According to the previous system of taxation, the tax on forest lands, as discussed above, was paid as a part of the rental fee for the special use of forest resources, while the amount of tax for the forests of the State Forestry Agency of Ukraine was 900 million UAH, of which 50\% was paid to the state budget, and $50 \%$ to the local budget. The net land tax was transferred to the local budget, calculated by non-forest land that is part of forestry land, which houses agricultural land, construction, administration of forestry enterprises, and electricity transmission lines, etc. The rate of the new land tax on forests is from $0 \%$ to $5 \%$ of the normative value of 1 hectare of forest land. Setting a specific rate depends directly on the decision of the city and village councils. However, when determining the rates of this tax, the specifics of forest resources should be taken into account.
According to the press service of the State Forestry Agency of Ukraine, the new land tax on forest land will lead to a rise in prices for wood and potentially stop forest reproduction in Ukraine (2018). For the total amount of revenue at almost 14 million UAH for 2017, the total amount taxes and other compulsory payments of forestry enterprises totaled more than 5 million UAH. In turn, an additional land tax will add from 3 to 10 million USD to this amount, depending on the decision of local communities. Such a tax burden will weaken the financial potential of forestry enterprises, which may lead to their insolvency (Neskorodeva, Pustovgar, 2015).

To summarize, the introduction of a new land tax on the forest will lead to a rise in prices for wood and a stop to forest reproduction in Ukraine, which can serve a number of negative impacts of the application of such a tax policy on forestry (http://dklg.kmu.gov.ua):

- for land that is in the stage of establishing tree-stands or growing plantations up to the age of 40 , and in which it is impossible to obtain timber suitable for sale, tax pressure will not only increase wood prices 1.5-2 times in the market, but also increase the cutting intensity and, respectively, decrease of forest quality;

- for all protective forests of the southern and eastern regions of the Steppe and Forest- 
steppe zones, leads to a significant increase in the cost of maintaining forests, as well as to the negative effects of forest fires and improper restoration of the forest fund without budget financing of forestry works;

- for forests with limited forest use, in reserves of regional and local significance, or other objects of the nature reserve fund, tax innovations will have a negative impact on the conservation of forest biodiversity and its qualitative composition and will significantly increase the cost of maintaining hunting farms.

We consider that the cancellation of dividends on profit will allow the private sector to be more public and will also enable forestry enterprises to use these funds for reforestation.

An analysis of the current situation indicates the economic inexpediency of the adopted innovations, which may eventually lead to a decline in forestry in general. Therefore, abolishing the amendments to the legislation for the new taxation of forestry land is necessary, and to bail forest enterprises out the situation, adopting laws necessary for the development of forestry.

\section{Conclusions and prospects for further research.}

In the course of the study of the current issues of taxation in the forestry sector of Ukraine, we concluded the current state of forestry in Ukraine is considered to be satisfactory. The most problematic issues in the operation of forestry enterprises that have been established are the increase in the forest area affected by wildfires (increase in the number of fires), the lack of budget funding for preventive forest management measures, the qualitative composition of staff, and the direction of state and local budgets to the development of forestry in Ukraine.

Taxation of forestry activities (payment of taxes, duties, and compulsory payments) is conducted without taking into account the specific nature of the use of natural resources.

Tax on land for forestry is granted as a rent for the special use of forest resources (more than 20 $\%$ in the structure of taxes, duties, and complusory payments paid in 2018, and provides $0.1 \%$ of tax revenues in the structure of the consolidated budget of Ukraine).

The results of the analysis of the current tax legislation of Ukraine have revealed the issues related to the taxation of forestry, in particular, an approach to the calculation and payment of a new land tax on forests (tax on forestry land). The application of rates for new taxes will lead to a rise in prices for wood and could potentially stop forest reproduction in Ukraine.

The use of rental payments to finance forest reproduction needs will promote environmenttally sustainable forest management.

The direction of further research would be to justify the environmentally-balanced use of forest resources on the basis of the application of special taxes, as well as the issue of valuation of property of forestry enterprises of Ukraine for tax purposes and optimization of tax calculations.

\section{REFERENCES}

Derzhavna sluzhba statystyky Ukrai'ny (2017). Indeksy spozhyvchyh cin u 1992-2017 rr. [Consumer price indices for 1992-2017]. Retrieved from: http://www.ukrstat.gov.ua/operativ/operati v2006/ct/cn_rik/isc/isc_u/isc_gr_u.htm [in Ukrainian]

Derzhavna sluzhba statystyky Ukrai'ny. Osnovni pokaznyky vedennja lisogospodars'koi' dijal'nosti (1990-2017) [Main indicators of forest management (1990-2017)]. Retrieved from:

http://www.ukrstat.gov.ua/operativ/operati v2014/sg/lis/lis_u/lgd2016_u.htm [in Ukrainian]

Derzhavna sluzhba statystyky Ukrai'ny (2018). Social'no-ekonomichnyj rozvytok Ukrai'ny za sichen'-serpen' 2018 roku [Socioeconomic development of Ukraine for January-August 2018]. Retrieved from: http://www.ukrstat.gov.ua/operativ/infograf ika/2018/soes/ukr/sed/ser_08_2018.pdf. [in Ukrainian]

Derzhavne agentstvo lisovyh resursiv Ukrai'ny (2017). Publichnyj zvit derzhavnogo agentstva lisovyh resursiv Ukrai'ny za 2017 
rik [Public report of the State Agency of Forest Resources of Ukraine for 2017]. Retrieved from:

http://komekolog.rada.gov.ua/uploads/docu ments/35328.pdf [in Ukrainian]

Derzhavne agentstvo lisovyh resursiv Ukrai'ny (2017). Strategija stalogo rozvytku ta instytucijnogo reformuvannja lisovogo ta myslyvs'kogo gospodarstva Ukrai'ny na period do 2022 roku [Strategy for sustainable development and institutional reform of forestry and hunting economy of Ukraine for the period up to 2022]. Retrieved from: https://drive.google.com/file/d/OB9CGEXC5V oa9MWZNbWZfY3BsdTg/view /in Ukrainian]

Derzhavne agentstvo lisovyh resursiv Ukrai'ny (2018). Novyj zemel'nyj podatok na lis pryzvede do zdorozhchannja derevyny ta zupynky lisovidtvorennja v Ukrai'ni [New land tax on forest will lead to a rise in prices for wood and stopping of forest reproduction in Ukraine]. Retrieved from: http://dklg.kmu.gov.ua/forest/control/uk/pu blish/article?art_id=194978\&cat_id=32888 [in Ukrainian]

Furdychko, O. I., Bobko, A. M. (2013) Zemli lisogospodars'kogo pryznachennja $\mathrm{v}$ ekologoekonomichnyh vymirah pry zemlevporjadkuvanni /Lands for forest management in ecological and economic measurements in land management]. Zbalansovane pryrodokorystuvannja, no. 23: 5-13 [in Ukrainian]

Garasym P., Klym N., Khomyak R. (2018) Features of Taxation of Forestry Enterprises//«Economics, Entrepreneurship, Management», Volume 5, Number 1, c. 5562

Gharasym P.M., Klym N.M. (2018) Rentna plata za specialjne vykorystannja lisovykh resursiv u bjudzhetnij systemi Ukrajiny [ Rent payment for special use of forest resources in the budget system of Ukraine] Proceedings of the Finansovyj rynok: instytuciji ta instrumenty (Ukrain, Lviv, June 3-6, 2018)Vydavnyctvo Ljvivsjkoji politekhniky, pp.26-28 [in Ukrainian]
Kudryk, M. T. (2009) Podatkove reguljuvannja systemy ekologichnyh innovacij v Ukrai'ni [Tax regulation of the system of ecological innovations in Ukraine]. Mehanizm reguljuvannja ekonomiky, no. 2: 218-228 [in Ukrainian]

Lebedevych, S. I. (2014) Oblikovo-audytors'ke zabezpechennja pidpryjemstv lisovogo gospodarstva dlja stalogo rozvytku Ukrai'ny [Accounting and auditing of forestry enterprises for sustainable development of Ukraine]. L'viv: Liga-Pres [in Ukrainian]

Len'o, R. V. Perspektyvni naprjamy vprovadzhennja zarubizhnogo dosvidu v systemu upravlinnja lisovym gospodarstvom Ukrai'ny [Perspective directions of introduction of foreign experience in forest management system of Ukraine]. Retrieved from:

http://academy.gov.ua/ej/ej16/txts/12LRVLG U.pdf [in Ukrainian]

Marchuk, Ju. Problemy finansovoekonomichnogo zabezpechennja lisovoi' polityky i shljahy i'h vyrishennja [Problems of financial and economic provision of forest policy and ways of their solution]. Retrieved from:

https://tlu.kiev.ua/fileadmin/user_upload/N asha_dijalnist/Suspilnii_dialog/Lisova_politi ka/Prezentacija_Marchuk_27.04.18.pdf [in Ukrainian]

Moroz, V. P. (2010) Dosvid zarubizhnyh krai'n shhodo opodatkuvannja lisovogo gospodarstva: ekologo-ekonomichni aspekty [Experience of foreign countries in relation to taxation of forestry: ecological and economic aspects]. Naukovyj visnyk NLTU Ukrai'ny, no. 20.5: 86-90 [in Ukrainian]

Neskorodeva I., Pustovgar S., (2015) An Approach to Predicting the Insolvency of Ukrainian Steel Enterprises Based on Financial Potential Journal of Eastern European and Central Asian Research, 2 (2).

Rentna plata za specvykorystannja lisovyh resursiv: osoblyvosti spravljannja u 2018 roci [Rent payment for special use of forest resources: features of harvesting in 2018]. Retrieved from: 
https://news.dtkt.ua/taxation/common/471 22 [in Ukrainian]

Synjakevych, I. M., Solovij, I. P., Vrublevs'ka, O. V. (2008). Lisova polityka: teorija i praktyka [Forest Policy: Theory and Practice]. NLTU Ukrai'ny. L'viv: LA "Piramida" [in Ukrainian]

Tkachiv, S. M. (2017). Opodatkuvannja lisovogo gospodarstva: problemy i perspektyvy [Forestry taxation: problems and perspectives]. Agrosvit, no. 14: 50-54 [in Ukrainian]

Tolchanova, Z. O. (2008). Shljahy reformuvannja lisovogo gospodarstva Ukrai'ny z urahuvannjam zakordonnogo dosvidu [Ways of reforming forestry of Ukraine taking into account foreign experience]. Ekonomika Ukrai'ny, no. 7: 103-107 [in Ukrainian]

Tunycja, Ju. Zvernennja zagal'nyh zboriv lisivnychoi' akademii' nauk ukrai'ny do Verhovnoi' rady Ukrai'ny i Kabinetu Ministriv Ukrai'ny [Appeal of the General Meeting of the Forestry Academy of Sciences of Ukraine to the Verkhovna Rada of Ukraine and the Cabinet of Ministers of Ukraine]. Retrieved from: https://tlu.kiev.ua/fileadmin/user_upload/N asha_dijalnist/Suspilnii_dialog/Lisova_politi ka/Zvernennja_zagalnikh_zboriv_Lisivnichoj i_akademiji_nauk_Ukrajini_do_Verkhovnoji _Radi_Ukrajini_i_Kabinetu_Ministriv_Ukraji ni.pdf [in Ukrainian]

Yaremko, I.., Plekan M., Kantslir I., Andrejkiv T. (2018). Informational and financial instruments for evaluation and management of the company's value Journal of Eastern European and Central Asian Research, 5(2).

Verkhovna Rada of Ukraine (2010). Podatkovyj kodeks Ukrai'ny [Tax Code of Ukraine]. Retrieved from: http://zakon.rada.gov.ua/laws/show/275517 (accessed 09 October 2018).

\section{ABOUT THE AUTHORS}

Oksana Hrytsak, email: grytsak_oks@ukr.net

Dr. Petro Harasym is a Professor at the Department of Accounting and Auditing of the Ukrainian National Forestry University. $\mathrm{He}$ is the author of 357 scientific and methodological publications, including 15 textbooks, 18 monographs, 195 scientific articles and abstracts of conferences of different levels. He was awarded with certificates of honor from the Ministry of Finance of Ukraine, the Council of Trade Unions of Employees of Financial and Banking Institutions of Lviv region, the Polytechnic of Lodz (Poland), and the University of Jan Kokhanowski in Kielce, Poland. The main areas of scientific activity are economic efficiency of production resources, improvement of accounting and tax accounting and financial reporting.

Dr. Nadia Klym is an Associate Professor at the Department of Accounting and Auditing of the Ukrainian National Forestry University. She is the author of more than 140 scientific, educational and methodological publications, including 4 textbooks and 4 collective monographs. Her scientific interests are organizational and economic aspects of improving the functioning of forestry enterprises in modern conditions of management; research of theoretical bases and practices of accounting, control and auditing, taxation and reporting at Ukrainian enterprises, use of computer technologies in accounting, analysis and auditing.

Dr. Oksana Hrytsak is an Associate Professor at the Department of Accounting and Auditing of the Ukrainian National Forestry University. She is the author of more than 30 scientific, educational and methodological publications devoted to accounting, auditing and analysis of economic activity. 